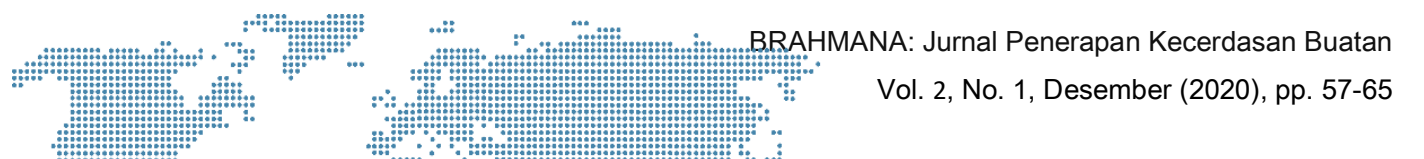

\title{
Inpiementasi Algoritma Weighted Product (WP) Dengan Model Fuzzy Multi t tribute: Decission Making (FMADM) Dalam Penilaian Kinerja Karyawan
}

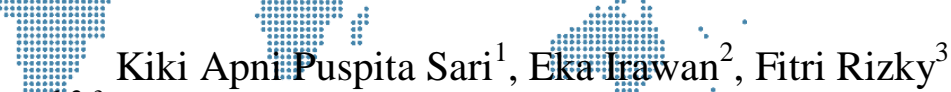

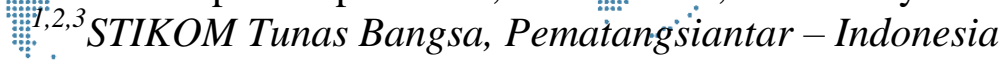

Jln. Sudirman Blok A No. 1-3 Pematangsiantar, Sumatera Utara

${ }^{1}$ kikiapnipuspitasari@gmail.com, ${ }^{2}$ ekairawan@stikomtunasbangsa.ac.id,

${ }^{3}$ fitri_rizki@stikomtb.ac.id

\begin{abstract}
Employee performance appraisal is a work evaluation activity that is used to determine the quality which will be used for the achievement of each individual employee. The purpose of this research is to appraise employee performance, especially for the security guard. In this study the authors used the Decision Support System technique using the Fuzzy Multi Attribute Decision Making algorithm, namely Weighted Product. The source of the research data used was to provide an assessment form to Krani Papam. In the employee performance appraisal, researchers used 5 assessment criteria, including: Attendance (C1), Responsibility (C2), Commitment (C3), Cooperation (C4), and Motivation (C5). In this study, the alternative used as a sample is employees in the security section (security guard). From the results of manual calculations and system testing, the highest value is 0.0286 . It is expected that the results of this study can provide input to the office, especially the security section (security guard) in selecting employee performance so that the assessment is carried out objectively.
\end{abstract}

Keywords : Spk, Employee Performance, Fuzzy MADM, Weighted Product.

\begin{abstract}
Abstrak
Penilaian kinerja karyawan merupakan suatu kegiatan evaluasi kerja yang digunakan untuk menentukan kualitas yang nantinya digunakan untuk pencapaian setiap masingmasing karyawan. Tujuan dari penelitian adalah untuk penilaian kinerja karyawan khususnya pada bagian satpam. Pada penelitian ini penulis menggunakan teknik Sistem Pendukung Keputusan dengan menggunakan algoritma Fuzzy Multi Attribute Decision Making yaitu Weighted Product. Sumber data penelitian yang digunakan adalah dengan melakukan pemberian form penilaian kepada Krani Papam. Pada penilaian Kinerja Karyawan peneliti menggunkan 5 kriteria penilaian antara lain: Kehadiran (C1), Tanggung Jawab (C2), Komitmen (C3), Kerja sama (C4), dan Motivasi (C5). Pada penelitian ini alternatif yang digunkan sebagai sample adalah Karyawan pada bagian keamanan (satpam). Dari hasil perhitungan manual dan pengujian sistem maka dapat dihasilkan nilai tertinggi yaitu 0,0286. Diharapkan Hasil penelitian ini dapat memberikan masukkan kepada pihak kantor khususnya bagian keamanan (satpam) dalam menyeleksi kinerja karyawan sehingga penilaian dilakukan secara objektif.
\end{abstract}

Kata Kunci : Spk, Kinerja Karyawan, Fuzzy MADM, Weighted Product.

\section{Pendahuluan}

Sistem Pendukung Keputusan merupakan sebuah sistem berbasis komputer yang dapat membantu dalam proses pengambilan keputusan. Sistem pendukung keputusan yang bersifat Adaptif, Fleksibel, dan Interaktif, yang dapat digunakan untuk memecahkan masalah-masalah yang tidak terstruktur sehingga dapat meningkatkan nilai keputusan yang akan diambil nantinya.Sistem Pendukung Keputusan dapat 


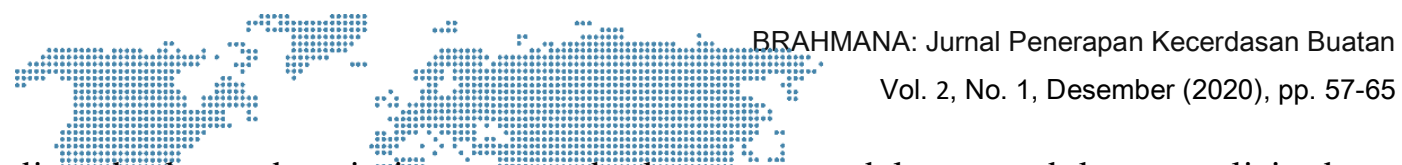

digambakkan sebagai sistem yang berkemanpuan dalam mendukung analisis data,

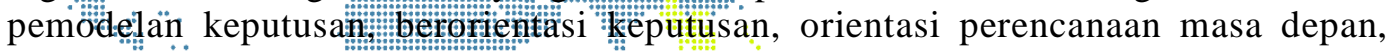

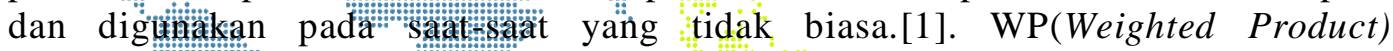
merupakân netóde sedên wank dengan perkalian untuk menghubungkan rating

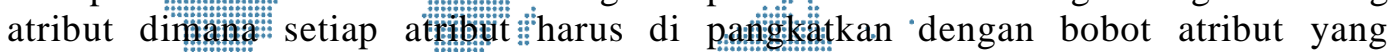
bersangkutan :[2] Weight Product Model merupakan suatu penerapan metode yang sangat banyak digunakan dalam menyelesaikan "suatu masalah. FMADM(Fuzzy Multi Attribüte Decision Making) merupakan suatu metode yang digunakan untuk mencari alternatif optimal dari sejumlah alternatif dengan kriteria tertentu. Selain itu, FMADM(Fuzzy Multi Attribute Decission Making) digunakan sebagai penentu bobot untuk setiap atribut yang nantinya akan dilanjutklan dengan proses perankingan yang akan menyeleksi alternatif yang telah ditetapka.[1].

Penilaian kinerja karyawan merupakan suatu kegiatan evaluasi kerja yang digunakan untuk menentukan kualitas yang digunakan untuk pencapaian setiap masing-masing karyawan. Setiap perusahaan pastinya memiliki standar dalam menilai setiap karyawannya. Namun, dalam perkembangan penilaian kinerja karyawan yang dilakukan kurang maksimal karena belum adanya sistem yang mendukung. Pada kesempatan ini penulis hanya berfokus pada penilaian kinerja karyawan pada bagian keamanan (Satpam) di PT Perkebunan Nusantara IV Bah Jambi.Satuan pengamanan yang selanjutnya disingkat Satpam merupakan satuan atau kelompok petugas yang dibentuk oleh instansi/badan usaha untuk melaksakan pengamanan dalam rangka menyelenggarakan swakarsa di lingkungan kerjanya. Dalam rangka meningkatkan kualitas produksi dan SDM, PT Perkebunan Nusantara terus menerus melakukan evaluasi dan dapat berkesinambung dalam segala hal, dan juga penilaian kinerja karyawan untuk menentukan manakah karyawan terbaik. Oleh karena itu dibutuhkan suatu algoritma yang dapat mempermudah dalam penilaian kinerja karyawan.

Beberapa penelitian terkait yang menggunakan metode Fuzzy Muti Attribute Decision Making (FMADM) dan Weight Product (WP) salah satunya seperti : [3] yang meneliti mengenai penentuan pegawai terbaik menggunakan metode Fuzzy Muti Attribute Decision Making (FMADM) dan Weight Product(WP), yang menggunakan 4 kriteria seperti kehadiran, kecepetan kerja, tanggung jawab dan kerja sama yang menghasilkan perhitungan tertinggi menggunakan sistem dan manual yang memiliki nilai yang sama. Selanjutnyapada penelitian [4] meneliti menggunakan metode Fuzzy Simple Additive Weighting (FSAW)seluruh kriteria di berikan bobot, jadi jika ada kekurangan disalah satu kriteria tidak terlalu berpengaruh pada penilaian. Sehingga dengan menggunakan metode Fuzzy Simple Additive Weighting (FSAW) sudah dapat berjalan dengan baik dandan dapat menghasilkan pembobotan kriteria yang jelas dan tepat dibanding manual.

Dalam hal ini peneliti ingin menggunakan SPK (Sistem Pendukung Keputusan) untuk melakukan perankingan dan mencari karyawan terbaik pada penilaian kinerja karyawan (Satpam) pada PT Perkebunan Nusantara IV Unit Bah Jambi. Diharapkan dengan adanya penelitian ini dapat digunakan sebagai salah satu dasar dalam pengambilan keputusan kepada pihak PT Perkebunan Nusantara IV Unit Kebun Bah Jambi dalam menilai kinerja karyawan khususnya pada bagian Satpam.

\section{Metodologi Penelitian}

\subsection{Sistem Pendukung Keputusan}

Sistem Pendukung Keputusan merupakan sebuah sistem berbasis komputer yang dapat membantu dalam proses pengambilan keputusan. "Sistem pendukung keputusan yang bersifat Adaptif, Fleksibel, dan Interaktif yang dapat digunakan untuk memecahkan masalah-masalah yang tidak terstruktur sehingga dapat meningkatkan nilai keputusan yang akan diambil nantinya"[1]. 


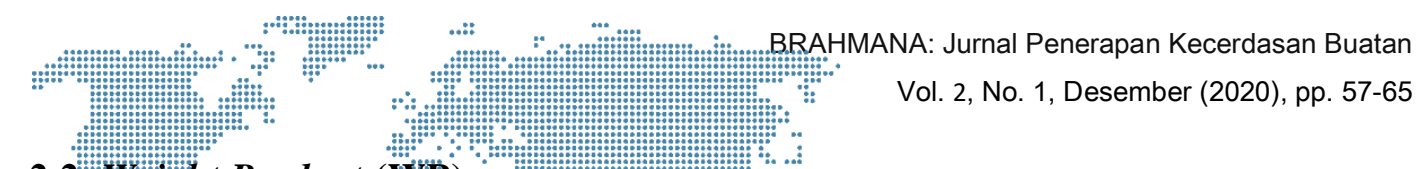

\subsection{Weetght Product (We}

Wezght Product (WI) netureak merupakan bagian dari konsep Multi Criteria

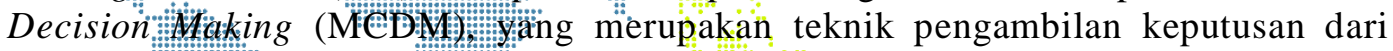
beberpa aituernatif. WP (Wetghted Product) mertipakan metode sederhana dengan

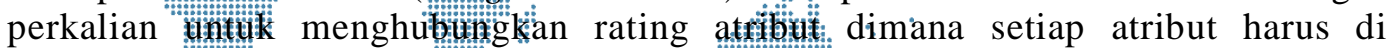
pangkatkan deengan bobot âtribut yang bersangkewte [2].

Dalam peenelitian ini penulis menggunakañ módel FMADM metode WP . Langkah - langkah penyelesaiannya adalah sebagai berikut [3] :

a) Menggunakan perkalian untuk menghubungkan rating atrubut

b) Rating setiap atribut harus dipangkatkan dulu dengan bobot atibut yang bersangkutan.

c) Dilakukan perbaikan bobot (W), sehingga menghasilkan bobot baru (W baru) seperti pada persamaan 1 .

$W_{j}=\frac{W_{j}}{\Sigma W_{j}}$

d) Mencari vektor $\mathrm{S}$ dan dilanjut mencari vektor $\mathrm{V}$ yang digunakan untuk perankingan. Metode WP menggunkan perkalian untuk menghubungkan rating atribut, dimana rating setiap atribut harus dipangkatkan dulu dengan bobot atribut yang bersangkutan atau bisa disebut proses normalisasi. Preferensi untuk setiap alternatif Ai diberukan seperti persamaan 2.

$S_{i}=\prod_{j=1}^{n} X_{i_{j}}^{w i_{j}}$

Dimana $\sum w j=w j$ adalah pangkat bernilai positif untuk atribut keuntungan , dan bernilai negatif untuk atribut biaya. Sedangkan preferensi relatif dari setiap alternatif, diberikan seperti persamaan 3 .

$V_{i}=\frac{\prod_{j=1}^{n} x_{i_{j}}^{w i_{j}}}{\prod_{j=1}^{n}\left(X_{j}^{*}\right)^{w j}}$

e) Hasil akhir perolehan dari proses perankingan yaitu menghasilkan nilai terbesar sehingga di peroleh nilai terbesar yang dipilih sebagai alternatif terbaik (Ai) sebagai solusi.

\section{Hasil dan Pembahasan}

Dalam penelitian, data yang digunakan akan diolah dari hasil wawancara dan kuesioner yang diberikan pada ketua papam (Keamanan) PT Perkebunan Nusantara IV kebun unit Bah Jambi. Sampel data yang digunakan sebanyak 46 sampel. Setelah data yang diperlukan diperoleh, Kemudian ditentukan atribut yang akan digunakan dalam penelitian. Atribut yang telah ditentukan ada 5 yaitu sebagai berikut :

1. Kehadiran

2. Tanggung Jawab

3. Komitmen

4. Kerja Sama

5. Motivasi

Pada penelitian ini penulis menggunakan metode Fuzzy Muti Attribute Decision Making (FMADM) dan Weight Product (WP) untuk mengolah data yang telah diperoleh dengan melakukan perankingan dalam penilaian kinerja karyawan.

Tabel 1. Hasil Rekapitulasi Data Kinerja Satpam

\begin{tabular}{|l|l|c|c|c|c|c|}
\hline \multirow{2}{*}{ No } & \multicolumn{1}{|c|}{ Nama } & \multicolumn{5}{|c|}{ Kriteria } \\
\cline { 3 - 7 } & & Kehadiran & $\begin{array}{c}\text { Tanggung } \\
\text { Jawab }\end{array}$ & Komitmen & $\begin{array}{c}\text { Kerja } \\
\text { Sama }\end{array}$ & Motivasi \\
\hline $\mathbf{1}$ & Wagirin & 8 & 8 & 7 & 8 & 7 \\
\hline $\mathbf{2}$ & Mesnan & 8 & 7 & 8 & 8 & 8 \\
\hline $\mathbf{3}$ & Suyanto & 7 & 7 & 7 & 8 & 7 \\
\hline
\end{tabular}




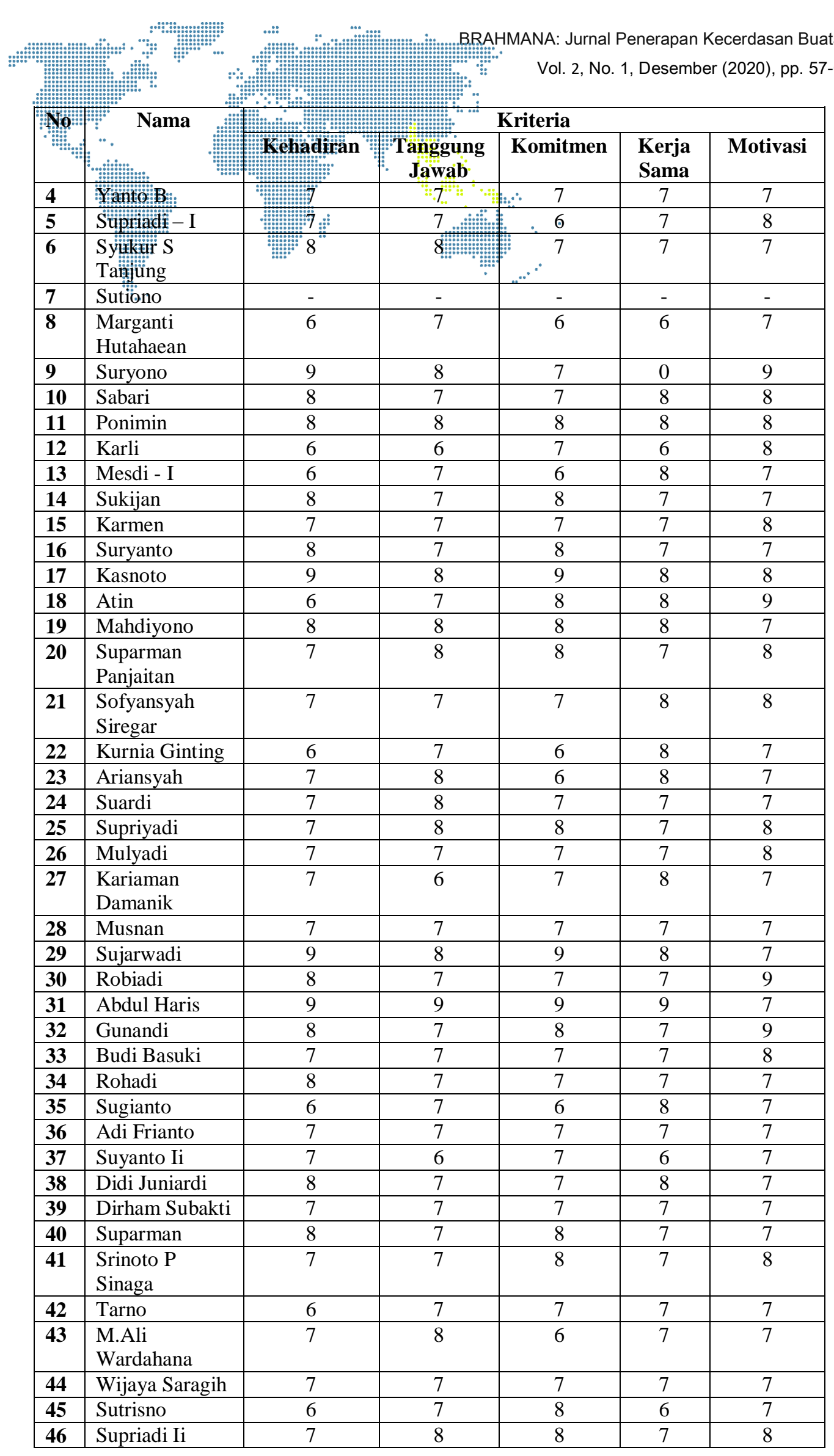

Adapun langkah-langkah penyelesaian dengan menggunakan Algoritma Weighted Product dengan Model Fuzzy Multi Attribute Decision Making yaitu sebagai berikut : 


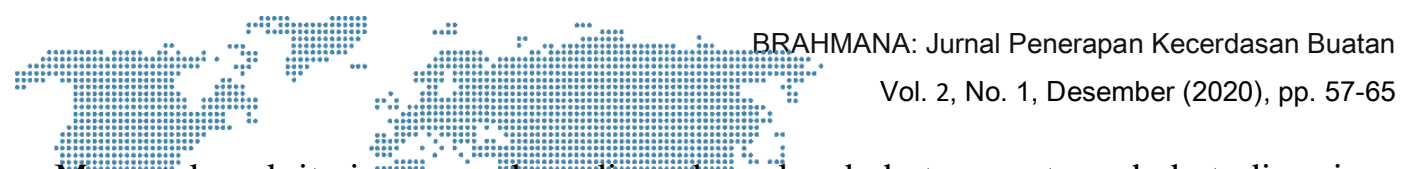

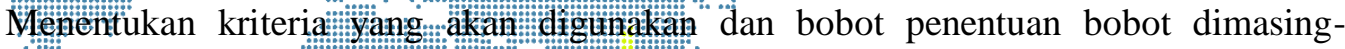

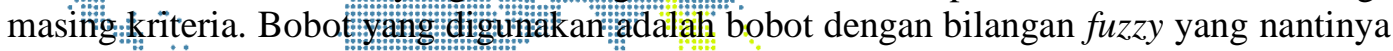

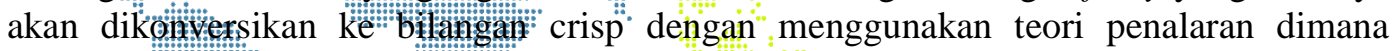
bilangan yang miendekati " 1 i tingkat ketergantungannya semakin tinggi. Pada bobot ini

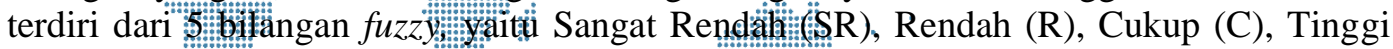
(T), dan Sanggat Tinggi (ST). Berikut hasi pen penentuan bobot dengan menggunakan bilangan fuz : Bobot pada bilangan Fuzzy:

Sangat Rendah $(\mathrm{SR})=0$

Rendah $(\mathrm{R})=0,2$

Cukup $(\mathrm{C})=0,5$

Tinggi $(\mathrm{T})=0,7$

Sanggat Tinggi $(\mathrm{ST})=1$

Tabel 2. Rating Kecocokan Kriteria Tehadap Alternatif

\begin{tabular}{|c|c|c|c|c|c|}
\hline Alternatif & C1 & C2 & C3 & C4 & C5 \\
\hline A1 & ST & ST & T & ST & T \\
\hline A2 & ST & T & ST & ST & ST \\
\hline $\mathbf{A 3}$ & T & T & T & ST & T \\
\hline A4 & T & T & T & T & T \\
\hline A5 & T & T & C & T & ST \\
\hline A6 & ST & ST & T & T & T \\
\hline A7 & C & T & C & C & T \\
\hline A8 & ST & ST & T & ST & ST \\
\hline $\mathbf{A 9}$ & ST & T & T & ST & ST \\
\hline $\mathbf{A 1 0}$ & ST & ST & ST & ST & ST \\
\hline $\mathbf{A 1 1}$ & C & C & T & C & ST \\
\hline$\ldots$ & $\ldots$ & $\ldots$ & $\ldots$ & $\ldots$ & $\ldots$ \\
\hline$\ldots$ & $\ldots$ & $\ldots$ & $\ldots$ & $\ldots$ & $\ldots$ \\
\hline $\mathbf{A 4 4}$ & C & T & ST & C & T \\
\hline $\mathbf{A 4 5}$ & T & ST & ST & T & ST \\
\hline
\end{tabular}

Setelah melakukan rating kecocokan terhadap setiap alternatif maka langkah selanjutnya yaitu melakukan penyelesaian dengan menggunkan metode WP dengan menggunakan model Fuzzy MADM. Sebelum melakukan perhitungan dengan menggunakan metode, terleih dahulu melakukan transformasi data yang sebelumnya menggunakan bilangan huruf Fuzzy di ubah menjadi bilangan angka Fuzzy agar dapat mempermudah dalam melakukan proses perhitungan.

Tabel 3. Transformasi Data

\begin{tabular}{|c|c|c|c|c|c|}
\hline Alternatif & C1 & C2 & C3 & C4 & C5 \\
\hline $\mathbf{A 1}$ & 1 & 1 & 0,7 & 1 & 0,7 \\
\hline $\mathbf{A 2}$ & 1 & 0,7 & 1 & 1 & 1 \\
\hline $\mathbf{A 3}$ & 0,7 & 0,7 & 0,7 & 1 & 0,7 \\
\hline $\mathbf{A 4}$ & 0,7 & 0,7 & 0,7 & 0,7 & 0,7 \\
\hline $\mathbf{A 5}$ & 0,7 & 0,7 & 0,5 & 0,7 & 1 \\
\hline $\mathbf{A 6}$ & 1 & 1 & 0,7 & 0,7 & 0,7 \\
\hline $\mathbf{A 7}$ & 0,5 & 0,7 & 0,5 & 0,5 & 0,7 \\
\hline $\mathbf{A 8}$ & 1 & 1 & 0,7 & 1 & 1 \\
\hline $\mathbf{A 9}$ & 1 & 0,7 & 0,7 & 1 & 1 \\
\hline $\mathbf{A 1 0}$ & 1 & 1 & 1 & 1 & 1 \\
\hline $\mathbf{A 1 1}$ & 0,5 & 0,5 & 0,7 & 0,5 & 1 \\
\hline $\mathbf{. .}$ & $\ldots$ & $\ldots$ & $\ldots$ & $\ldots$ & $\ldots$ \\
\hline $\mathbf{. .}$ & $\ldots$ & $\ldots$ & $\ldots$ & $\ldots$ & $\ldots$ \\
\hline $\mathbf{A 4 4}$ & 0,5 & 0,7 & 1 & 0,5 & 0,7 \\
\hline $\mathbf{A 4 5}$ & 0,7 & 1 & 1 & 0,7 & 1 \\
\hline
\end{tabular}




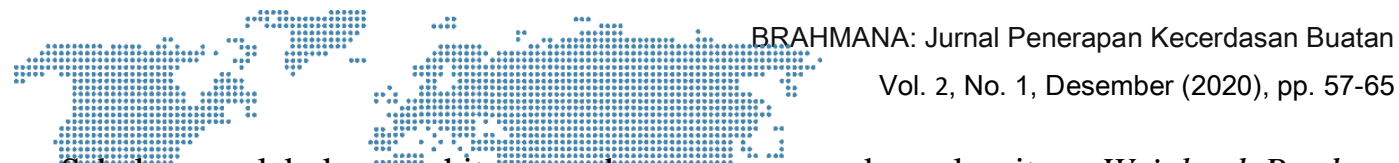

Sebeltim melakukañiterhittugan dengan menggunkan algoritma Weighted Product,

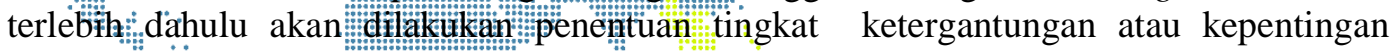

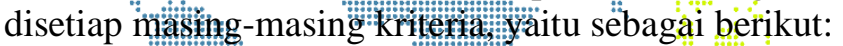

\begin{tabular}{|c|c|c|c|c|}
\hline Kriteria & Keterangan & Ketergantuna aan & Nilai Crisn & Kenentingan \\
\hline G1 & Kehadiran & Tinggi & $\because 0,7$ & Benefit \\
\hline $\mathrm{C2}$ & Tanggung Jawab & Sangat Tinggi & 1 & Benefit \\
\hline C3 & Komitmen & Cukup & 0,5 & Benefit \\
\hline C4 & Kerja Sama & Rendah & 0,2 & Benefit \\
\hline C5 & Motivasi & Rendah & 0,2 & Benefit \\
\hline
\end{tabular}

Pengambilan keputusan memberikan bobot dan perbaikan bobot kriteria, berdasarkan kepentingan dari masing-masing kriteria yang nantinya akan menghasilkan bobot baru.

Tabel 5. Hasil Perhitungan W Baru

\begin{tabular}{|c|c|c|}
\hline W & Perhitungan W baru & Hasil \\
\hline W1 & $\frac{0,7}{0,7+1+0.5+0.2+0.2}$ & 0,2692 \\
\hline W2 & $\frac{1}{0,7+1+0.5+0.2+0.2}$ & 0,3846 \\
\hline W3 & $\frac{0.5}{0,7+1+0.5+0.2+0.2}$ & 0,1923 \\
\hline W4 & $\frac{0.2}{0,7+1+0.5+0.2+0.2}$ & 0,0769 \\
\hline W5 & $\frac{0.2}{0,7+1+0.5+0.2+0.2}$ & 0,0769 \\
\hline
\end{tabular}

Setelah menentukan bobot baru, maka selanjutnya menentukan nilai vektor $\mathrm{S}$ dengan cara mengalihkan setiap data nilai alternatif rating kecocokan yang berpangkat positif dari perbaikan bobot tadi. Berikut adalah contoh perhitungan manual untuk mencari vektor $\mathrm{s}$ : $S 1=\left(1^{0,2692}\right) \times\left(1^{0,3846}\right) \times\left(0,7^{0,1923}\right) \times\left(0,7^{0,0769}\right) \times\left(1^{0,0769}\right)=0,9084$ $S 1=\left(1^{0,2692}\right) \times\left(0,7^{0,3846}\right) \times\left(1^{0,1923}\right) \times\left(1^{0,0769}\right) \times\left(1^{0,0769}\right)=0,8718$

Berikut adalah hasil perhitungan vektor $S$ :

Tabel 6. Hasil Vektor $S$

\begin{tabular}{|c|c|}
\hline Alternatif & Vektor $\mathbf{~}$ \\
\hline S1 & 0,9084 \\
\hline S2 & 0,8718 \\
\hline S3 & 0,7195 \\
\hline S4 & 0,7000 \\
\hline S5 & 0,6744 \\
\hline S6 & 0,8839 \\
\hline S7 & 0,5840 \\
\hline S8 & 0,9337 \\
\hline S9 & 0,8140 \\
\hline S10 & 1,0000 \\
\hline S11 & 0,5626 \\
\hline$\ldots$ & $\ldots$ \\
\hline$\ldots$ & $\ldots$ \\
\hline S44 & 0,6673 \\
\hline S45 & 0,8839 \\
\hline \multicolumn{2}{|c}{}
\end{tabular}

Hasil dari penentuan vektor S, maka selanjutnya menentukan nilai vektor $\mathrm{V}$ dengan menggunakan nilai vektor $\mathrm{S}$ yang nantinya akan menghasilkan alternatif 


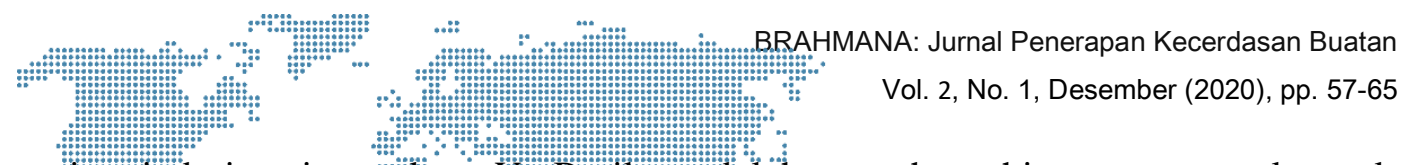

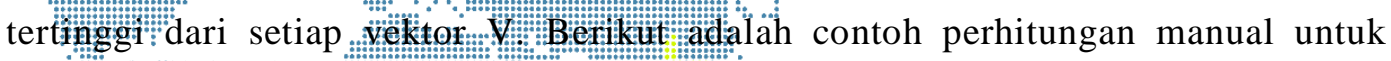
mencari nillai vektor

$\frac{0,9084}{34,8082}=0026$. Berikut hasil perhitungan dari vektor V :

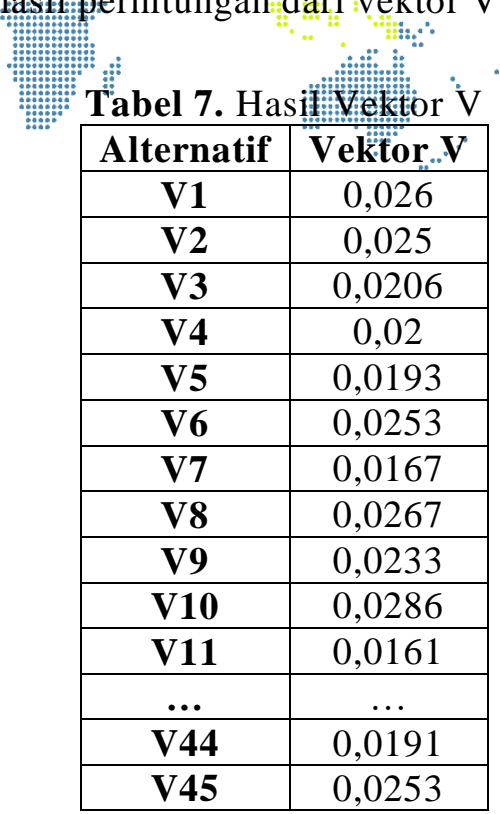

Setelah dilakukan perhitungan vektor V maka akan dihasilkan nilai tertinggi dan juga ranking tertinggi. Dari tabel diatas diperoleh nilai tertinggi ada pada A10 dan A16 dengan nilai $\mathrm{V}=0,0286$. Sehingga dapat dijadikan alternatif terbaik dan dapat direkomendasikan dalam penilaian kinerja karyawan.

Selanjutnya dilakukan pengujian data menggunakan sistem. Pengujian yang digunakan untuk menguji perhitungan manual yang telah dilakukan adalah dengan menggunakan program berbasis web. Adapun kebutuhan sistem yang digunakan dalam pendataan sistem pendukung keputusan dalam penilaian kinerja karyawan terbaik meliputi kebutuhan software dan kebutuhan hardware.

1) Kebutuhan Software, meliputi :

a. Web sebagai aplikasi bahasa pemrograman yang digunakan.

b. Xampp sebagai server

c. Sublime Text 3 sebagai aplikasi desain form

2) Kebutuhan Hardware, meliputi :

Dalam mengoperasikan aplikasi ini hardware yang dibutuhkan harus berteknologi multimedia dan memiliki komponen hardware minimal :

a. Processor minimal setara Dual-Core

b. Memory ram $2 \mathrm{~Gb}$

c. Hardisk minimal $500 \mathrm{~Gb}$

Dan berikut adalah tampilan dari hasil vektor v yang merupakan hasil akhir dari pengolahan data menggunakan sistem:

\begin{tabular}{|c|c|c|c|}
\hline Rank & Kode & Alternatif [Pegawai] & Skor Akhir (N. Pref. (V)) \\
\hline 1 & 010 & A10 & 0.0286 \\
\hline 2 & 016 & A16 & 0.0286 \\
\hline 3 & 028 & A28 & 0.0278 \\
\hline 4 & 030 & A30 & 0.0278 \\
\hline 5 & 018 & A18 & 0.0278 \\
\hline 6 & 008 & A8 & 0.0267 \\
\hline 7 & 001 & A1 & 0.026 \\
\hline 8 & 019 & A19 & 0.0253 \\
\hline 9 & 024 & A24 & 0.0253 \\
\hline 10 & 045 & A45 & 0.0253 \\
\hline
\end{tabular}




\begin{tabular}{|c|c|c|c|c|}
\hline \multicolumn{3}{|c|}{ : } & $\begin{array}{l}\text { • } \\
\text { • }\end{array}$ & $\begin{array}{l}\text { NA: Jurnal Penerapan Kecerdasan Buata } \\
\text { Vol. 2, No. 1, Desember (2020), pp. 57-6 }\end{array}$ \\
\hline 11 & 006 & A6 & 0.0253 & \\
\hline 12 & 002 & A2 & 0.025 & \\
\hline 13 & 031 & A31 & 0.0243 & \\
\hline 14 & 039 & A39 & 0.0236 & \\
\hline 15 & 015 & A15 & 0.0236 & \\
\hline 16 & 013 & A13 & 0.0236 & \\
\hline 17 & 009 & A9 & 0.0233 & \\
\hline 18 & 023 & A23 & 0.023 & \\
\hline 19 & 037 & A37 & 0.0227 & \\
\hline 20 & 029 & A29 & 0.0227 & \\
\hline 21 & 022 & A22 & 0.0221 & \\
\hline 22 & 040 & A40 & 0.0221 & \\
\hline 23 & 033 & A33 & 0.0221 & \\
\hline 24 & 042 & A42 & 0.0215 & \\
\hline 25 & 020 & $A 20$ & 0.0212 & \\
\hline 26 & 017 & A17 & 0.0207 & \\
\hline 27 & 003 & A3 & 0.0206 & \\
\hline 28 & 032 & A32 & 0.0206 & \\
\hline 29 & 014 & A14 & 0.0206 & \\
\hline 30 & 025 & A25 & 0.0206 & \\
\hline 31 & 043 & $A 43$ & 0.02 & \\
\hline 32 & 004 & A4 & 0.02 & \\
\hline 33 & 035 & A35 & 0.02 & \\
\hline 34 & 027 & A27 & 0.02 & \\
\hline 35 & 038 & A38 & 0.02 & \\
\hline 36 & 005 & A5 & 0.0193 & \\
\hline 37 & 044 & A44 & 0.0191 & \\
\hline 38 & 041 & A41 & 0.0183 & \\
\hline 39 & 026 & A26 & 0.0181 & \\
\hline 40 & 021 & A21 & 0.0176 & \\
\hline 41 & 012 & A12 & 0.0176 & \\
\hline 42 & 034 & A34 & 0.0176 & \\
\hline 43 & 036 & A36 & 0.0172 & \\
\hline 44 & 007 & A7 & 0.0167 & \\
\hline 45 & 011 & A11 & 0.0161 & \\
\hline
\end{tabular}

Gambar 1. Hasil Vektor v

Setelah melakukan perhitungan dengan menggunakan sistem dengan metode FuzzyWP maka dihasilkan nilai akhir tertinggi yaitu 0,0286. Begitu juga dengan melakukan perhitungan manual dengan excel yang menghasilkan hasil yang sama seperti yang dihasilkan pada sistem. Maka dengan dilakukannya perhitungan secara manual, excel ataupun dengan menggunakan program yang telah dibuat menghasilkan hasil yang sama dan dapat dikatakan berhasil.

\section{Kesimpulan}

Adapun kesimpulan yang dapat diambil pada Implementasi Algoritma Weighted Product (WP) dengan model Fuzzy Multi Attribute Decision Making (FMADM) adalah sebagai berikut :

a) Penerapan metode WP dengan Model Fuzzy MADM dalam penilaian kinerja karyawan dengan menggunakan program berbasis web dapat membantu pihak manajemen dalam melakukan penilaian terhadap karyawannya.

b) Dengan menerapkan program metode WP dengan Model Fuzzy MADM berbasis web dapat menghasilkan nilai yang sama dengan nilai perhitungan manual dan dengan menggunakan excel . Nilai tertinggi yang dihasilkan adalah 0,0286, Dengan menggunakan kriteria-kriteria seperti : Kehadian, Tanggung Jawab, Komitmen, Kerja Sama dan Motivasi.

\section{Daftar Pustaka}

[1] D. Lidia Purwani, R. Renaldo, Nungsiyati, And M. Muslihuddin, "Model Kebijakan Prioritas Dalam Upaya Meningkatkan Kinerja Pdam Kab. Pringsewu Menggunakan Fuzzy Atribut Decission Making (Fmadm) Dengan Metode Simple 


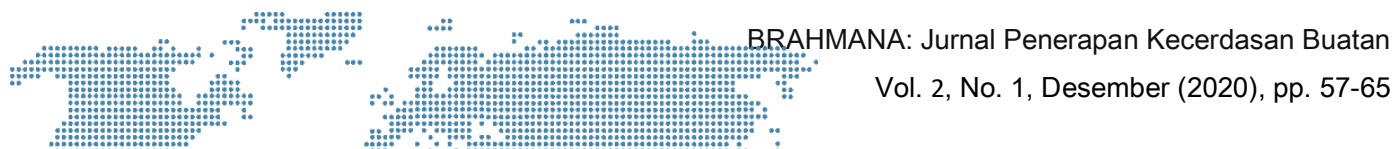
Additive Weighting (Saw) X Mance. Sitst. Inf. Dan Teknol., Vol. 06, No. Kinerja

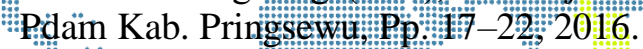

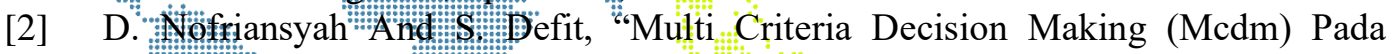

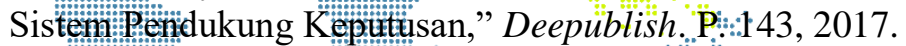

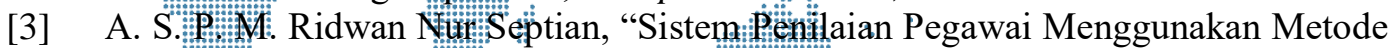
Fuzzy Multiple Attribute Decision Making (1:inadm) Dan Weighted Product (Wp)," Vol. X: No. X, Pp. 27-33, 2017.

[4] F. Agustini And E. R. Ariska, "Penerapan Metode Simple Additive Weighting (Saw) Dengan Model Fuzzy Model Attribute Decision Making (Fmadm) Penilaian Kinerja Karyawan Dtpeduli,” J. Techno Nusa Mandiri, Vol. 16, No. 1, Pp. 21-28, 2019, Doi: 10.33480/Techno.V16i1.107. 